\title{
REASON, EXPERIENCE, AND LANGUAGE TO ACQUIRE KNOWLEDGE (IN WESTERN AND ISLAMIC PERSPECTIVES)
}

\author{
Mudjia Rahardjo
}

m_rahardjo2003@yahoo.com

Universitas Islam Negeri Maulana Malik Ibrahim

Malang, East Java, Indonesia

\begin{abstract}
The system of knowledge acquisition is one of the most important topics in philosophical debates since ancient Greek. According to the Western philosophical worldview, as the universally accepted method, there are two schools of thought to acquire proper knowledge; rationalism and empiricism. Rationalism assumes that sound reason is the main human potential to acquire knowledge that constitutes a priori knowledge, while empiricism relies on sensory abilities constituting a posteriori or empirical knowledge. In addition, Islam offers intuition or instinct as another source of knowledge that creates intuitive knowledge, be it empirical or spiritual. The knowledge gained is then developed through language symbols, from being personal to finally public knowledge. Through language, knowledge is inherited from one generation to the next. However, due to its limitations, language is not able to symbolize all types of knowledge. Consequently, there are two kinds of knowledge; articulated (explicit) knowledge and unarticulated (tacit) knowledge. Nevertheless, despite their sharp differences, both the Western and Islamic worldviews assume that knowledge acquisition is the field of a speculative philosophical endeavor which is hard to get a satisfying answer, though it is not impossible.
\end{abstract}

Keywords: knowledge, reason, experience, rationalism, empiricism, intuition.

\section{INTRODUCTION}

Unlike any other creatures, human beings are curious to know things that make them identified as knowledge seekers. According to Wagdid (in Wan Daud, eds., 2010, p. 103), the purpose of seeking knowledge for human beings is not only to inculcate goodness or justice as a social citizen or integral part of society, but also it is men's value as real men in their microcosmic lives. In other words, the purpose of knowledge is to produce a good man (woman) to produce a good society since society is composed of people. Therefore, making everyone or most of them good produces a good society.

The question about knowledge and how to acquire it is one of the central concerns of philosophers since ancient times. The problem is how to acquire knowledge? It is an epistemological question in philosophy that is not simple to answer. It invites serious debates among philosophers. The central aim of philosophy is to find the most reasonable answer to various fundamental questions in which science often cannot provide the answers adequately. The question becomes more complicated when followed by "objective" answers. The words "objective" or "subjective" are philosophical terms that are understood differently among philosophers.

Among philosophers, there has been a long and interesting debate on the question about which is more important, either reason or experience, to obtain knowledge. Then, a further question follows: what kind of standard we are to use to define a philosophical answer to the question. In the theory of knowledge, the question has confronted us with a very sharp distinction between two kinds of knowledge: $a$ priori (obtained from logic by thinking) and 
empirical (from experience by knowing through senses). We should realize that most of our knowledge is obtained by observing the external world (sense perception) and ourselves (introspection). It is called empirical knowledge. However, some knowledge we can obtain by simply reasoning or thinking. Contrast to empirical knowledge, that kind of knowledge is called a priori. Its chief exemplifications are to be found in logic and mathematics. In order to see that $3+6=9$, we do not need to take three things and six things. Nevertheless, we just put them together and then count them. Then, we can know the total number of things easily.

Rationalists would prefer to say that logic or reason is more important to acquire knowledge. It is to say that belief in the logic or reason about something is more important than knowing or experiencing things. All scientific activities, such as research, from selecting themes to formulating results, are processes of reasoning that run logically. With logic, humans can reason logically to determine truth. The reasoning is a form of thinking. To achieve that, the reasoning is compartmentalized from existing knowledge. This kind of truth is called "a truth of reasons" and does not rely on observation.

On the other hand, empiricists would argue that knowing or experiencing is more important because, through experience, an objective reality may be obtained. Objectivity is one of the requirements for the validity of scientific knowledge. For example, to be able to feel cold, one has to touch the ice. Likewise, when a person wants to feel the heat, he has to touch the fire, and so on. Thus, knowledge is the essence of experiencing. Experiencing is more than just reasoning or thinking.

In philosophy, this debate has entered the realm of the epistemology of knowledge, and epistemology is one of the important pillars in a philosophy that deals with obtaining knowledge and examining how science is accounted for. A question about rationalism and empiricism is nothing but a problem of "ideas" and "facts." According to David Hume, one of the great philosophical figures of all time, all human reasons and inquiry may naturally be divided into "Relations of Ideas" and "Matters of Facts." The first is discoverable by the mere operation of thought, while the second is through the operation of senses by observation.

Epistemology of knowledge has contributed greatly to human life. The complexity and richness of the realities that exist in this world can be revealed to the development of science. With their logic, scientists can uncover hidden or undiscovered realities. Through language, the knowledge gained becomes articulated knowledge. Knowledge is initially personal. When it is used, it becomes public knowledge. Language can exist as a symbol of an experience or even a very abstract understanding. This article will explain the role of reason, experience, and language in search of knowledge. Put simply, this article will answer a philosophical question: which one is more important, either reason or experience, to acquire knowledge?.

To answer the question, some philosophical references are used, namely. The logic of Scientific Discovery by Popper (1961), Philosophy of Science: A Very Short Introduction by Okasha (2002), An Introduction to the Philosophy of Science by Bortolotti (2008), Knowledge, Language, Thought and the Civilization of Islam, Essays in Honor of Syed Muhammad Naquib al-Attas, edited by Al-Attas (2010), Al-Ghazali's Concept of Causality, regarding His Interpretations of Reality and Knowledge by Zarkasyi (2010). To enrich the discussion, some Islamic perspectives are used and written in a separate sub-chapter. To clarify the discussion, the terms logic, reason, thinking are used interchangeably.

Using an interpretive paradigm, this study applies a narrative study. Interpretivism recognizes that knowledge is not only discovered but also constructed. The construction is done through literary analysis thoroughly and comprehensively by (1) reading the whole texts on philosophy of sciences and Islamic worldview, (2) relating certain texts with their corresponding texts (co-texts and inter-texts), and their countertexts, (3) identifying and comparing different types of ways of acquiring knowledge, (4) recognizing a variety of strategies to justify the arguments, assess the strengths and weaknesses of each thought, and (5) identifying some key aspects of acquiring knowledge in both the Western philosophical and the Islamic Worldview. 


\section{Reason and Experience in Philosophical Review}

Socrates, one of the great Greek thinkers in the philosophical tradition, lived in 469-399 $\mathrm{BC}$, who held the view that humans are born and equipped with logic/reason and make themselves special beings compared to others. Some call it "mind." Since then, philosophers have continued to discuss the role of reason in the search for knowledge. The longer the human being, the more he put a great deal of confidence in the ability to reason. Armed with the power of reason, humans want to live freely and organize themselves without the pressure of any force that shackles them. Thus, logic can produce knowledge in its way, without the aid of other organ or organs. Thought that greatly exalts reason is called rationalism, which later became one of philosophy's primary schools of thought-the rationalists against lazy people to think and indulge in the will outside of themselves.

Rationalism results in a priori knowledge or 'intuitive knowledge' (Derksen \& Gartell, 2006 , p. 2463), namely knowledge from mind processing that starts from a set of axioms about several phenomena and then develops knowledge about it using reasoning and logic that works in a system that is limited by these axioms, so that it is similar to belief (Tarigan, 1992 , p. 10). An example of a priori knowledge is $5+6=11$. To prove that 5 plus 6 becomes 11 , we do not need to take objects or objects totaling 5 and 6 and then combine them, but it is sufficient to use reason (Erwing, 1951, p. 542). Another example is that three times five equals half of thirty expresses a relation between these figures. The proposition is discovered without dependence on what is anywhere existent or appears in the universe.

The idea of Socrates' rationalism was continued by Rene Descartes (1596-1650), a French philosopher, Spinoza (1632-1677), and Leibniz (1646-1716). They are the figures behind rationalism who contributed a lot to the method of scientific inquiry. As a human being from birth, reason is not only the main source of reliable knowledge but is also used to measure whether knowledge is true or not. Therefore, only knowledge obtained from reason fulfills scientific requirements. Logic does not require experience in obtaining proper knowledge because reason can derive truth from itself. In another expression,
Riyanto (2018, p. 138) that knowledge exists in one's mind, which has a categorical structure.

According to Descartes (in

Poedjawijatna, 2004, p. 57), the reason is a gift from God before humans are born to become a provision for their life, so it is impossible if God's gift is not true. Another argument Descartes uses is an appeal to logical possibility: God could have made us with "memories" of events that never happened, or He could have made us so that arguments that strike us as sound ones are not.

Through rationalism, Descartes taught humans to exploit their potential in seeking scientific knowledge. All the search for knowledge through research, which begins with the search for phenomena, data collection, data analysis to formulating findings and results, requires the power of critical, detailed, in-depth, and holistic analysis that reason can do. Rationalists also believe that reason not only produces knowledge but is also the main source of knowledge itself.

Since Descartes' era, all human beings have been called "rational" creatures, in the sense that humans ask questions and are constantly looking for answers. The famous Descartes expression is "I think, so I exist." According to him, something that is true based on the human mind does not need proof. This thought is often referred to as the thought of Cartesian rationalism (borrowing the name Descartes). Apart from inviting us to think rationally, Descartes also teaches us to learn to sort complex problems into fragmented parts so that they can be easily overcome (Muadz, 2013, p. xi). So fundamental is Descartes' way of thinking about the investigation of knowledge that he is called the "father of modern science."

Equipped with reason, the research seeks to interpret and make sense of the data and information provided by the informants through reflection, research experience, and personal intellectual creativity. Everything that is collected is then interpreted. According to Watloly (2001, p. 143), interpretation is a combination of the complexity of the relationship between truth and error. Truth, in essence, is a knowledge product of mental processes after an error has been found.

Rationalism relies on the truth of coherence, relies on the deductive inference method so that the essence of the conclusion is 
the derivation of general things. Coherence means that knowledge is developed in a consistent line of thought, and all components are integrated as a whole. Knowledge is considered wrong if the arguments are inconsistent and intact based on previous knowledge, which is assumed to be true. Rationalism invites us to respect existing works. That is why there is a special section that discusses theories and findings that have been uncovered and discovered by predecessors in scientific work. Rationalism exists as a force that defeats the myths that developed in primitive societies. The history of modernity is the history of rationalism. According to Hardiman (1994), the human ratio has shown itself as a "new myth" in the form of science, which later developed into "scientism." The ratio is exalted as the producer of science.

Based on rationalism, research methods, especially qualitative research, provide a very wide space for researchers to develop the mental processes between researchers and research subjects through intensive interactions. Putting themselves outside the research subject, qualitative researchers want to gain a deep understanding of phenomena or events from the actor's side. The vast space to explore the meaning of an event under study allows researchers to have a broad view and think critically because an order of values or structures does not confine them. Being critical with distrust and doubting on something that is not yet clear is an instinctive human talent.

With their logic/reason, humans can make abstractions and concepts of countless realities and interpret them to give birth to knowledge. According to Muhadjir (2007, p. 2), history proves that the development of science is dominated by deductive thinking. That is, the rational ability to abstract and conceptualize reality apart from empirical facts turns out to be more dominant in the development of science. It is in line with Eisner's (in Taylor \& Wallace, 2007, p. 46) statement which states:

"...human knowledge is made, not simply discovered, that what we know is a product of our minds as well as of what may exist outside the mind".

Reason can construct human knowledge into scientific knowledge. According to AzZuhaili (2002, p. 133), human reason has succeeded in proving innovation and creation and being artistic in all fields related to the company, agriculture, and trade. Intellect does not allow what is on land, sea and air, and the universe, but it fills it with amazing creations and innovations.

In addition, Az-Zuhaili (2002) mentions, in an Islamic perspective, a strong call from Allah to utilize reason in exploring nature and its various benefits and think in optimizing its abilities is shown by Allah in the Qur'an by mentioning the word "al aqlu" to the very least. Fifty times, "ulil albab" twenty times, and "uulin nuha" twice. Because thinking is a tool for innovation and creation, neglecting the function of reason and thinking is a striking phenomenon of underdevelopment. It all indicates that thinking is an Islamic obligation that is no different from other obligations. Without a sense, humans become weak and anxious. He cannot distinguish between guidance and error, good and evil.

Even though the influence of rationalism is so great in the world of science and philosophy, it turns out that not all philosophers and thinkers can accept this school of thought. Rationalism is believed to find difficulties when faced with a definite 'truth.' Because each person has a measure of truth according to his rationality, it is difficult to obtain a consensus about the truth. The critics of rationalism state that humans are born without an idea or reason; when a man was born, he was like a paper or board without writing (tabula rasa). Only from his observations, humans gradually have an idea or reason. Empirical facts, captured through experience, are the main source of knowledge (Pateda, 2001, p. 14). Because of this, a new school of thought called empiricism was established.

Aristotle (384-322 BC) thought that reason was not the proper tool for seeking knowledge but observation through the senses. From senses, human beings may obtain knowledge. Empiricism does not recognize $a$ priori knowledge; on the contrary, what exists is a posteriori knowledge, namely knowledge obtained based on things that come or happen later. This kind of knowledge is sometimes called empirical knowledge. True knowledge can be proven by prior experience. Knowledge must be objective (following the object or reality). Empiricism relies on the truth of correspondence and relies on inductive 
inference so that the essence of the conclusion is that inferences from specific things are then made into general things. Correspondence means that there is an agreement between the statement and reality. Knowledge is considered wrong if the statement and reality do not match, let alone contradict.

By witnessing an accident, watching the thermostat, mixing oil and water in the kitchen, or observing a rare eclipse with our naked eye, we acquire beliefs about the behavior of things and people around us. In all these cases, we have direct experience of what happens, what we see or feel, and gain that experience largely by observation. More often, our beliefs come from indirect sources, some trustworthy than others (e.g., relevant experts, teachers, books, $\mathrm{TV}$, internet, hearsay, tradition) (Bortolotti, 2008, pp. 31-32). We often believe in them, though we do not experience them yet. It is to justify that there are beliefs that we derive from prior beliefs.

Empiricism first appeared in England in the 15th century, with Francis Bacon (1561$1626)$ as the forerunner. Bacon introduced the experimental method to research. According to him, through experience, humans can know things and the laws of relations between things. Empiricism bases its views on the physical, material aspects, and the fulfillment of the physical domain as the center of happiness. This school of thought gets more and more established in strengthening its influence. Besides Bacon, Thomas Hobbes (1588-1679) is a figure of empiricism whose thoughts align with Bacon's (Sumarna, 2005, p. 67).

David Hume well developed this thought (1711-1776), influenced by Aristotelian thought. There is another assumption that the five senses cannot tell a lie. If there is an error in the knowledge obtained, the cause is human interpretation himself, not because of the senses. How knowledge is developed through experience is a central part of empiricism (Wuisman, 1996: 5). According to Tarigan (1992, p. 11), sensory competence is used to find out something through processes of investigation or experimentation, which then becomes one of the strategies in quantitative research. Empirical knowledge is obtained by interacting with the real world, observing phenomena, and drawing conclusions from experience.
The separation between instinctive and sensory knowledge is considered inappropriate by some. However, Carrel (in Watloly, 2001, p. 141) states that sensory knowledge is indeed obtained from the power of the human senses but is always relational. It means that through their senses, humans can perceive reality as an abiotic creature. However, reality is also inseparable from the psychic process.

Since each person has different sensory powers and the characteristics of the object to be perceived are different, it is hard to obtain the same empirical knowledge for all people. Each of the senses perceives a different aspect of the object or thing. According to Carrel, sense knowledge varies according to the difference in the senses and is limited to the sensibility of certain sense organs. For example, hearing can only perceive sound; the eye can only see something concrete. The eye cannot pick up on smells, which only the sense of smell can pick up on. Likewise, the other senses are only able to perceive reality from the surface side. Thus, sensory knowledge by Watloly (2001, p. 142) is called incomplete knowledge because it is only captured by one sense. According to Soekadijo (1999, p. 3), along with sensory activity, thought activities occur. This type of ideal knowledge does not yet have a solid objective basis. However, whatever is the condition, empirical knowledge is basic knowledge that is very important for obtaining further knowledge.

Though a priori and a posteriori knowledge sound logical, philosophers in general and philosophers of science in particular, according to Botolotti (2008, p. 31), think very carefully about ways to acquire, process, and organize knowledge. It may invite further debates. Botolotti exemplifies that at any time, we have several different beliefs, for instance, that tomorrow it will rain or that $2+2$ $=4$. Tomorrow, it will rain is called an $a$ posteriori statement; that is, its truth or falsehood depends on how the world will be tomorrow and cannot be established without relying on some form of evidence (sense experience or testimony). That $2+2=4$ is an $a$ priori statement as its truth or falsehood depends on mathematics conventions. No evidence can be brought to bear on the statement's truth, and the statement itself does not offer any description of empirical facts. 
We believe that $2+2=4$ because we were taught that this is the case when we first learned maths at school, and becoming proficient in these basic calculations, was part of how we started understanding the concept of numbers and operations such as sums and subtractions. We maintain the beliefs we acquired in this way unless we challenge the conventions of mathematics. Hence, a priori knowledge can also be obtained from prior belief.

\section{Knowledge in Islamic Perspective}

Islam is the religion that considers knowledge in great concern. Therefore, any attempt to acquire knowledge is highly appreciated. The Holy Qur'an and Hadits of Prophet Muhammad (PBUH) mention many times the importance of pursuing knowledge for Muslims. The core of knowledge is 'ilm.' The term 'ilm,' according to Zarkasyi (2010, p. 146), is obviously of Qur'anic origin, and this is the major impetus that pervades the Muslim mind to seek its definition and structure, or pattern and develop it into various branches projecting the worldview of Islam. However, there are varieties of definitions of knowledge that are confusing. Zarkasyi (2010) mentions that the Muslims' attempt to explain "what knowledge means" and find out an acceptable definition for it is a part of their endeavor to grasp the knowledge of God about the world, life, man, faith, reason, ethic and the like. In addition, secular schools define knowledge as due to nefarious attempts made by anti-religious individuals, usually known as sophists, and this is to confuse the idea that was already stated in the Muslim mind.

There is a sharp distinction between the Western worldview and Islam in understanding knowledge. In Islam, knowledge means certainty (al-yaqin) as opposed to doubt or conjecture. According to Jah (in Al-Attas, 2010, p. 87), there are three levels of al-yaqin, namely: (1) knowledge of certainty, which corresponds to knowledge acquired through sound reason, (2) certainty itself, corresponding to knowledge arrived at through observation, and (3) true knowledge or true certainty, which corresponds to direct experience, that is the intuitive knowledge, be it empirical (scientific discovery) or spiritual (inspiration).
According to al-Attas, reason and experience as the only sources of knowledge, identified by modern philosophers from ancient Greek philosophers such Socrates and Arsitoletes, and further developed by Descartes and David Hume, cannot lead to true certainty or absolute reality, which leaves no room for doubt. In addition, according to Imam Ghazali (in Zarkasyi, 2010, p. 145), the concept of knowledge is very much related to his concept of reality. In Ghazali's thought, the reality is not limited to changing, external and sensible reality but also includes permanent, transcendental, and Absolute Reality. Accordingly, those realities require sense perception, observation, logical inference, intuition, and true reports based on authority. It is so different from Western philosophical perspectives that there are only two sources of knowledge; reason and experience. The issue of knowledge is not only defining what knowledge is, but also its classification, its subject, or the knower and the object, the process through which the knower apprehends the object, to what extent the knower knows the object of knowledge, whether the knower can attain the knowledge with certainty and the like.

Related to certainty, the Holy Qur'an has mentioned this by saying in Surah Yunus, verse 36, "Assuredly, conjecture can by no means take the place of truth (al-yaqin). By saying so and referring to Al-Qur'an, it does not mean that science and logical reason have no value. On the contrary, when rightly used, they can constitute a sound basis for proper knowledge. From the above definition of knowledge, one can see the difficulty in using a relativistic materialistic philosophy to get access to the true knowledge of al-yaqin to help a man know how to exercise his freedom of choice. Nevertheless, it is what distinguishes the worldview of Islam from the modern secular worldview of the West. Islam recognizes three sources of knowledge; sound reason, sound experience, and the authority of al-Qur'an and hadits of the Prophet Muhammad (PBUH).

In Islam, it is believed that proper knowledge comes from Allah, the creator of the universe. From an Islamic perspective in the Qur'an and the teaching of the Prophet Muhammad, Allah provides man with the knowledge to know his creator, himself, the environment, and the universe. By 
approaching this knowledge of al-yaqin, man will acquire discipline and wisdom, which are prerequisites for justice. According to alQur'an, uncertainty cannot lead to the truth.

The worldview of Islam is challenged by globalization because of the latter's uncertain and unpredictable nature. Under these circumstances, decision-making concerning social, cultural, and political matters affecting Muslim societies becomes difficult, if not impossible. According to this materialistic philosophy, there cannot be absolute truth or certainty. Accordingly, no reality can be established without reason or experience. In other words, realities have to be experiential and verifiable using reason and experience. Knowledge is defined as the arrival in the soul of the meanings of things and the ability to recognize the proper place of things in the order of creation.

The Western worldview does not recognize the existence of Allah as the creator and sustainer of the universe, nor does it believe in the absolute truth or unseen realities and therefore does not recognize the metaphysical realities and the accountability in the life to come. This worldview is based on secular materialism and is defined as a coherent collection of concepts and theorems that allows man to construct a global image of the world he lives in. The worldview of Islam defines how people relate to their creator Allah SWT in the act of submission, worships, and obedience to Him. It also defines how they relate to one another and the physical environment and nature as a whole in the act of recognition of divine will. For Muslims, Islam represents a way of life guided by proper knowledge and ethical principles outlined in the Holy Qur'an and exemplified in the practical life of the Prophet Muhammad (PBUH).

Referring to al-Attas' perspective, Jah (2010, p. 84) states that"The man of Islam has with him the Qur'an which is itself unchanged, unchanging and unchangeable; it is the speech of God revealed in complete and final form." Thus, what is meant by a worldview of Islam is "the vision of reality and truth that appears before our mind's eye revealing what existence is all about; for it is the world of existence in its totality that Islam is projecting."

In contrast to Islam, the Western worldview conceives this physical world as an eternal, independent, and self-subsistent system evolving according to its laws. In such a system, man is seen as his own master; man needs no authority to guide him; he is, therefore, free to do what he wants, hence man's problem in this life. There is no doubt that such a Western philosophical worldview influences not only the issue of how to acquire knowledge but also in how men behave and act in practical life. Various kinds of crimes, violence, drug abuse, alcoholism, prostitution, pornography, homosexuality, and the likes are easily found in the West and have reduced the value and meaning of life.

\section{Language and Knowledge}

It is undeniable that language is a very important instrument to acquire knowledge. Language does not only function as a means of communication but is also a means of scientific thinking and a means of conveying the results of scientific thought. Thus, language is a form of thought content and a tool or instrument of the thought process. However, language is also not only a dead tool of the mind. Outside of logic, language has other roles in life.

Because of its arbitrariness, language can very freely assign symbols or names to reality. However, apart from giving names or symbols, language is also a repository for a large collection of deposits of collective human knowledge (archeology of knowledge), which can be reopened at any time when needed. Therefore, it is very important for anyone who is about to enter the world of knowledge in general to understand the relationship between language and thinking.

In this connection, philosophers question which is first and more important between language and thought? Can language grow without thinking? Is it possible to think without language? These are perhaps some of the questions that are so tempting to ponder over and over again.

Indeed, not many philosophers or scientists have paid enough attention to the relationship between language and thought, let alone related to civilization. One could mention these small numbers, among others, Thomas Hobbes, Ludwig Wittgenstein, Ernest Cassirer, and Michael Polanyi.

Thomas Hobbes, a prominent British philosopher, questioned, "what enables human knowledge to continue to develop?" His 
contemplation concluded that the peculiarity of man lies in his ability to mark every reality symbolically.

Humans can form symbols or give names to mark each reality, whereas animals cannot do all of that. Because there is a preparation of these names, humans can recall and relate them to one another. Science and philosophy were born possibly because of the human ability to formulate words and sentences. Therefore, human knowledge also takes two different forms: knowledge of reality and consequences.

"Science and philosophy are possible because of man's capacity to formulate words and sentences. Knowledge, then, takes on two different forms, one being knowledge of reality, and the other knowledge of consequences." 1

As a result, it becomes quite easy for us to understand the statement of the famous language philosopher Ludwig Wittgenstein that "the limit of my language is the limit of my world" (Die Grenzen meiner Sprache bedeuten die Grenzen meiner Welt)2.If language deficiency is the limit of the animal kingdom, then language deficiency also limits the human world. Therefore, even if it is desired to expand the human world, one of the main tools is language proficiency.

Ernest Cassirershifted the locus of his philosophical studies on the problem of the relationship between language and thought. Although on a different field of study, the results remind Emile Durkheim's landmark of the peculiarities of an extraordinary thinker.

Ernest Cassirer also resulted in a conclusion that was different from the tendency of ordinary thinking. If most of us believe that the main differentiator of humans from animals is their ability to think, then Cassirer asserts that humans are so special because of language. Erving Goffman's expression,"...human beings are symbol-using creatures",3is the same and congruent with the mention of Cassirer that humans are animal symbolicum $^{4}$

${ }^{1}$ Sakban Rosidi, The History of Modern Thought, (Malang: Center of Inter-Disciplinary Study and Cooperation, 2002) p.28.

${ }^{2}$ Ludwig Wittgenstein, Tractatus Logico-Philosophicus, (London: Routledge \& Kegan Paul, 1972), p. 115.
Philosophically, the statement 'humans use symbols" has a broader scope than the statement 'humans think' (homo sapiens) because only when using language can humans think coherently, regularly, sophistically, and abstractly. Furthermore, all collective human achievements, such as the repertoire of scientific knowledge, advancement of civilization, and cultural glories, almost certainly cannot be realized without the role of language as the main prerequisite.

Without language, there is no human ability to pass on values, behavior patterns, and cultural objects from one generation to the next. Moreover, it may also be much more difficult to imagine cultural enrichment through exchanges between groups of people without language.

So far, language has made the most important contribution to mankind. However, as described by Michael Polanyi, a Hungarian philosopher, there is a paradox in the relationship between language and knowledge. On the one hand, language allows humans to share, pass on, and develop the results of thoughts, including knowledge. However, on the other hand, language also tends to simplify the facts that science should explain and even predict because of its inevitable nature.

Polanyi classified two types of human knowledge (See Fig. 1). According to him, from the fact (the whole reality) which is almost unlimited, a small part of it is the fact that is known (the known reality) of humans, thus giving birth to knowledge. Furthermore, of the vast amount of knowledge that is still extraordinary, most of it is still pre-articulated knowledge, while a small portion of it is articulated knowledge. Consequently, it is impossible to draw any other conclusions, except that humans know more than they can say (we know more than we can say). ${ }^{5}$
${ }^{3}$ Ray P. Cuzzort and Edith W. King, Social Thought, (Colorado: Holt, Rinehart and Winston, 1990) p. 287. ${ }^{4}$ Ernest Cassirer, An Essay on Man, (New Haven: Yale University Press, 1944).

${ }^{5}$ Michael Polanyi, The Study of Man, (Chicago: The University of Chicago Press, 1959). 


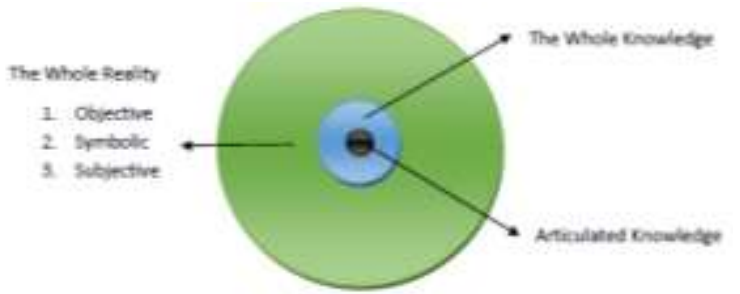

Figure 1. The links between reality, knowledge, and linguistic knowledge

What we talk about every day as knowledge, referring to Polanyi's thoughts, is nothing but linguistic knowledge. Every item of human knowledge originally comes from personal knowledge. Only when the owner of knowledge can pronounce his knowledge will this kind of knowledge become objective knowledge because it can be discussed and even tested by others. Even so, there is still so much human knowledge that remains as tacit knowledge. For example, our knowledge of all tastes, such as spicy, sweet, sour, salty, and many others, still fails to increase its degree to language knowledge. Apart from taste, color, sound, and smell, it is also unfamiliar knowledge. For example, all dark colors are simply called 'black.' There are various qualities about 'dark.' Likewise, the sound is only called loud or soft. The volume of the sound also varies.

Nevertheless, there are only two types of voices that are used, loud and soft. The word 'rotten' represents various types of odors. Colors, sounds, tastes, and smells cannot essentially be called material things.

As a result, language also has several weaknesses. First, due to limited vocabulary, not all facts can be revealed. Finally, multiple or complex realities are only represented by a symbol or word. Representatives certainly cannot represent all those who are represented. There must be parts that are not represented. Second, language has a reductionist nature of the meaning of reality which is often not realized by language users. The reduced meaning of reality can lead to misunderstanding. At a broader level, it can lead to conflict. Third, written words or expressions uttered by someone have a certain meaning. However, the true intentions are not always visible to the surface. The real meaning must be traced from things outside the language, such as tone, body language (gesture) of the user, and the context that surrounds it.

There is no doubt that language plays an important role in acquiring knowledge. However, as stated by Okasha (2002, p. 52), that modern science, including language or linguistics, can explain a great deal about the world we live in. Nevertheless, there are still numerous facts that have not been explained by science, or at least not explained fully, and therefore left unanswered. However, this does not deny the fact about the role of language in search of knowledge since it is the language that makes a priori knowledge possible as a genuine source of new knowledge. All a priori propositions, according to Ewing (1951, p. 549), are a matter of arbitrary linguistic convention (language). So we must reject any attempt to explain away the a priori as a genuine source of new knowledge since, in philosophy, knowledge cannot be based merely on observation. Besides, it is the language that inherits knowledge from one generation to the next one. So, there is no doubt to state the important role of language in acquiring or developing human knowledge.

\section{CONCLUSION}

The question about 'reason' and 'experience' in acquiring knowledge is one of the central issues in philosophy for a long time. Both produced two schools of thought; rationalism and empiricism. If rationalism produces a priori type of knowledge, called "truth of reason," empiricism is a posteriori or empirical knowledge. If true knowledge according to rationalism is to be logical, then empiricism must be objective. On the other hand, if the process of acquiring knowledge in rationalism is deductive, empiricism is inductive.

Placed in the philosophy of idealismrealism continuum, the combination of rationalism and empiricism resulted in two major paradigms in research, namely positivism and interpretivism. Positivism is the philosophical root of quantitative research methods, while interpretivism is the philosophical basis of qualitative research methods. If rationalism is based on logic and empiricism is an empirical reality, logical and empirical knowledge are the valid requirements for measuring scientific knowledge. The reason is to abstract the world 
of reality into concepts, make analysis, and interpret it to produce new knowledge.

Through language, the knowledge already obtained is symbolized to become articulated knowledge. Here, language functions as a symbol of knowledge or reality, either concrete, abstract or symbolic. Unfortunately, not all knowledge and realities can be symbolized by language. Due to the limitation of language, there is considerable knowledge and realities still left unarticulated. In addition, it is the language that makes $a$ priori knowledge possible through an arbitrary linguistic convention.

In addition to rationalism and empiricism, Islam offers another source of knowledge: intuition from which men may get intuitive knowledge. As a religion, Islam accepts absolute truth or certainty (al-yaqin). Besides, Islam recognizes more comprehensive ways to guide human life, not only in acquiring knowledge but also in conducting life under moral and respected values. Thus, Islam encompasses life in both a-dunya and alakhirah (today in this world and the day after). However, due to the massive globalization, there is no doubt that the Western worldview (materialism) will have considerable influence on Muslims' worldview in all aspects.

\section{REFERENCES}

Al-Attas, M. N. (2010). Knowledge, Language, Thought, and the Civilization of Islam: Essays in Honor of Syed Muhammad Naquib Al-Attas. Penerbit UTM Press.

Az-Zuhaili, Wahbah (2002). Al Qur'an Menjawab TantanganZaman. (Alih Bahasa oleh Syarif Hade Masyah dan Ali Efendi Anshori). Jakarta Selatan: Penerbit Mustaqim.

Bartolotti, Lisa. (2008). An Introduction to the Philosophy of Science. Cambridge CB2 IUR, UK: Polity Press.

Derksen, Linda and Gartell, John. (2006). "Scientific Explanation" in Edgar F. Borgotta and Rhonda J.V. Montgomery (eds.). Encyclopedia of Sociology, Volume 4.Qualitative Methods to Sociolinguistics. New York: Macmillan Reference. The USA.

Ewing, Alfred Cyril. (1951). 'Criticism of the Linguistic Theory of the A Priori.' Anonim. Fundamental Questions of Philosophy. London: Routledge \& Kegan Ltd., New York: The Macmillan Company.

Hardiman, F. Budi. (1994). "Ilmu-Ilmu Sosial dalam Diskursus Modernisme dan Pasca-Modernisme". Ulumul Qur'an. Jurnal Ilmu dan Kebudayaan. Nomor 1, Volume V, Th.1994.

Muadz, M. Husni. (2013). Anatomi Sistem Sosial: Rekonstruksi Normalitas Relasi IntersubyektivitasRekognitif dengan Pendekatan Sistem. Mataram: Institut Pembelajaran Gelar Hidup.

Muhadjir, Noeng. (2007). Metodologi Keilmuan. Paradigma Kualitatif, Kuantitatif dan Mixed. Yogyakarta: Penerbit Rake Sarasin.

Okasha, Samir. (2002). Philosophy of Science. A Very Short Introduction. Oxford: University Press.

Jah, Omar. (2010). "Al-Balagh." In Wan Moh Nor Wan Daud \& Muhamamad Zainy Uthman (eds.). 2010. Knowledge, Language, Thought and the Civilization of Islam. Essays in Honour of Syed Muhammad Naquib al- Attas. Malaysia: Universiti Teknologi Malaysia.

Pateda, Mansoer. (2001). Semantik Leksikal. Jakarta: PT Rineka Cipta. 
Patton, Michael Quinn. (1990). Qualitative Evaluation and Research Methods. (second edition). London, New Delhi: Sage Publications.

Poedjawijatna, I.R. (2004). Logika Filsafat Berpikir. Jakarta: PenerbitRineka Cipta.

Popper, Karl R. (1961). The Logic of Scientific Discovery. New York: Science Editions, Inc.

Riyanto, F.X. Eko Armada. (2018). Mendesain Riset Filosofis - Fenomenologis dalam Rangka Mengembangkan "Berfilsafat Indonesia". Dalam A. Tjatur Raharso dan Yustinus(ed.). Metodologi Riset Studi Filsafat Teologi. Malang: PenerbitDioma.

Riyanto, F.X. Eko Armada. (2018). Relasionalitas: FilsafatFondasi Interpretasi: Aku, Teks, Liyan, Fenomen. Yogyakarta: Penerbit PT Kanisius.

Riyanto, F.X. Eko Armada. (2018). "Tradisi Riset Studi Widya Sasana (1971-2000): Membangun Integrasi-Kontekstualisasi Filsafat Teologi". Dalam A. Tjatur Raharso dan Yustinus (ed.). Metodologi Riset Studi Filsafat Teologi. Malang: Penerbit Dioma.

Soekadijo, R.G. (1999). Logika Dasar. Tradisional, simbolik, dan induktif. Jakarta: Penerbit PT Gramedia Pustaka Utama.

Sumarna, Cecep. (2005). Rekonstruksi Ilmu: dari Empirik-Rasional Ateistik ke Empirik-Rasional Teistik. Bandung: Benang Merah Press.

Tarigan, Henry Guntur. (1992). Prinsip-Prinsip Dasar MetodeRiset Pengajaran dan Pembelajaran Bahasa. Bandung: Penerbit Angkasa.

Taylor, Peter Charles, and Wallace, John (eds.). (2007). Qualitative Research in Postmodern Times. Exemplars for Science, Mathematics, and Technology. AA. Dordrecht, The Netherlands: Springer.

Wagdid, Yusef. "Reflections on Al-Attas' Conception of the Islamic University" in Wan Moh Nor Wan Daud \& Muhammad Zainy Uthman (eds.). (2010). Knowledge, Language, Thought and the Civilization of Islam. Essays in Honour of Syed Muhammad Naquib al- Attas. Malaysia: Universiti Teknologi Malaysia.

Watlolly, Aholiab. (2001). Tanggung Jawab Pengetahuan.Mempertimbangkan Epistemologi secara Kultural. Yogyakarta: Penerbit Kanisius.

Wuisman J,J,J. M. (1996). Penelitian Ilmu-ilmu Sosial. Jilid1Asas-asas. (Penyunting M. Hisyam). Jakarta: Penerbit Fakultas Ekonomi Universitas Indonesia.

Zarkasyi, Hamid Fahmy. (2010). Al-Ghazali's Concept of Causality. With reference to His Interpretations of Reality and Knowledge. Malaysia: IIUM Press. 
LiNGUA Vol. 16, No. 1, June 2021 • ISSN 1693-4725 • e-ISSN 2442-3823 